\title{
ACQUIRING ENGLISH THROUGH MATHEMATICS: A CASE STUDY ON A BILINGUAL EDUCATION
}

\author{
Aulia Apriana \\ Universitas Negeri Malang \\ LiaZagladi@yahoo.com
}

\author{
Sri Rachmajanti \\ Universitas Negeri Malang \\ loeksr@gmail.com
}

\section{Evynurul Laily Zen}

Universitas Negeri Malang

evynurullailyzen@yahoo.com

\begin{abstract}
This study aims at examining the process acquiring a second language through Mathematics subject among the students of Laboratory Primary School of Universitas Negeri Malang, which is a university-based laboratory primary school whose curriculum reflects the result of a synergy between the National Curriculum of Indonesia and International Framework. In this school, English becomes the medium of instruction in two school subjects, Science and Mathematics. The design of the study is descriptive qualitative which attempts to describe the process of acquiring English through Mathematics class. The subjects in this study were 16 third graders who belong to the International Class Program (ICP). The results of the analysis showed that the students' language comprehension was in fact greater than their language production. Finally, it is concluded that teaching Mathematics in English facilitates the learners' attempt in learning English.
\end{abstract}

Keywords: Bilingual education, English language acquisition,

Mathematics, Language Learning

\section{INTRODUCTION}

Indonesia is now facing the Global Market era, which means that every one of us is required to equip ourselves with an international language, that is English. Therefore, many parents nowadays tend to send their children to English courses in order to give them additional English training to complement what they get from schools. To answer this demand, Universitas Negeri Malang, through its several laboratory schools (Kindergarten, Primary School, Junior and Senior High Schools, and School for the Autistic), has offered a synergy of the National Curriculum of Indonesia and the International Framework, so that the students can get adequate exposure to English from the schools. These schools have been implementing content subjects in English as a medium of instruction since 2006.

The laboratory schools of Universitas Negeri Malang were founded in 1984 under the management and funding of a private educational foundation. Since July 2009 , the lab schools have been affiliated into the management of the university. These schools are under the management and responsibility of a board namely 'Institute for Developing Laboratory of Education' (Institute for Developing Laboratory of Education Document, 2010). The institute has then set up the ultimate outcome of the lab school graduates which is in accordance with the university's vision and mission that in the academic area, the graduates are expected to become independently competent in science, technology, and arts as well as strong in character. The previously mentioned goals are aligned with the national and international standards.

The setting of this study is the Laboratory Primary School of Universitas Negeri Malang, which has two types of classes, Bilingual classes and International classes. In the bilingual classes, the learners are taught through English as the medium of instruction in the school subjects, Science and Mathematics since they sit in the first grade, while in the international classes, the lower classes (1st-3rd grades) are taught in full English and the upper classes (4th-6th grades) are taught in bilingual system, i.e. in Indonesian and English. This is intended to prepare the learners for the national as well as the international examinations. As a consequence, the school also issues double certificates for the learners: one for the School-Based Examination and/or the National Examination, and the other for International standard framework tests. In the long run, it is expected that the graduates of this Primary School will be well-equipped to face the challenges of AFTA and MDG when the time comes for them.

The present study is conducted as an attempt to measure the English language acquisition of the students of the Laboratory Primary School of Universitas Negeri Malang as an impact of their exposure to English language while they have Mathematics class, which is taught in English. The bilingualism of these students is considered interesting to investigate because of the students' very young age (starting from 6 or 7 years old). Bilingualism itself is defined as the ability of a person to 
understand and produce several languages (Steinberg, 1993; Crystal, 2003; O'Grady et al, 2005; Parker \& Riley, 2005; Darmojuwono, S \& Kushartanti, 2005; Saville-Troike, 2006). Specifically, Butler \& Hakuta (2006) also state that a bilingual is a person who has the ability to communicate in various competences, spoken or written, in two or more languages.

However, bilingualism is actually not a new phenomenon in the context of language acquisition of a child. There are many researches done on this issue, most of which are focusing on whether bilingualism brings positive or negative impact toward the language acquisition of a child. Crystal (2003:365) is one of many experts who believes that bilingualism will bring negative consequences because the brain actually cannot proceed two language systems at the same time. In other words, bilingualism will cause imperfection in the first and second language acquisitions. On the other hand, Peal and Lambert (1962), Bruck, Lambert, and Tucker (1976), and Bain \& Yu (1980), elaborated by Steinberg, et al (2001), show a different perspective. Peal and Lambert (1962) had conducted an intelligence test toward 164 monolingual and bilingual primary school students and the results show that bilingual students exceed the monolinguals. The researchers then hypothesize that the bilingualism of a child makes his mental and cognition flexible and rich. Bruck, Lambert, and Tucker (1976) also gave a test of creativity and language competence toward two groups of monolingual and bilingual students in a total immersion program of French. The results show that the bilingual students are better in the creativity test and their second language competences are native-like. Another experiment was done toward some bilingual students from many countries (Alberta, Canada, Alsace, France, and Hong Kong) by Bain and Yu (1980) which resulted a fundamental finding that bilingual children are better in cognitive performance tests compared to the monolinguals, which then leads to another hypothesis about the superiority of bilingual children.

Therefore, in this present study, the researchers are trying to measure the language competence and performance of the students of Laboratory Primary School of Universitas Negeri Malang in order to reveal the impact of the bilingual education program held by the school toward the language acquisition of the students and their cognitive development.

\section{METHOD}

The design of the study was descriptive qualitative which attempted to describe the process of acquiring English through Mathematics class. As Fraenkell dan Wallen (1993:380) said that when the data are in the form of description, the best design to employ is descriptive qualitative. The subjects of the study were 16 third graders of Laboratory Primary School of Universitas Negeri Malang, East Java, Indonesia, who were in the second semester of the academic year 2014-2015. The learners belonged to the International Class Program (ICP) in which English was used as the medium of instruction for two other subjects besides English class, those are Mathematics and Science. Yet, for this study, the focus was on the teaching of Mathematics in English. However, since the ICP actually consisted of 2 (two) parallel classes, only one was treated as the subject of this research. They had learned Mathematics for three years starting from Grade 1, consuming 2 times 40 minutes twice a week. Hence, since the moment the learners were involved in the study, they had acquired the content of Mathematics in English for almost 3 (three) years.

To obtain data to respond to the study questions, several instruments were use; such as documents on the school guideline, the framework of Mathematics, a questionnaire, classroom observation sheets, and 15 test items on Mathematics Inquiry. Each of them was analyzed accordingly that all written documents were elaborated descriptively, and the test on Mathematics was scored and then the linguistic elements in the test were analyzed to examine the learners' English language comprehension and production. The data collection was conducted at the school for 2 (two) months.

\section{FINDINGS}

From the 16 students taking the test, the scores are ranging from 16.35 to 75.77 . These students are thus classified into 3 (three) groups: 1) High Achievers (score 60.38 to 75.77); 2) Middle Achievers (score 51.73 to 58.08); and 3) Low Achievers (score 16.35 to 46.54). In terms of language comprehension, it was determined that 1 ) the high achievers $(31 \%)$ comprehended most the meaning of technical terms related to words and phrases on Mathematics, kinds of sentences like declarative statements, instructions, and questions, 2) the mid achievers (38\%) understood some of the meaning of technical terms related to words and phrases on Mathematics, kinds of sentences like declarative statements, instructions, and questions, and 3) the low achievers $(31 \%)$ understood a few of the meaning of technical terms related to words and phrases on Mathematics, kinds of sentences like declarative statements, instructions, and questions.

In terms of language production, 1) the high achievers were competent to write correct words such as one hundred and fourteen, five hundred and fifty three, fifteen, fifty six, one hundred and fourty three, seven hundred and seventy two, sixteen, two hundred and fifty seven, four hundred and fifty five, one hundred and eighty four, twenty thousand rupiahs, four thousand rupiahs, and one hundred eighty 
six thousand rupiah, 2) the mid achievers can write such words as one hundred and fourteen, five hundred and fifty three, fifty five, fifty six, three hundred and fourty four, seven hundred and seventy two, eleven, two hundred and seventy five, four hundred and five, one hundred eighty four, ten thousand, two thousand, and one hundred thousand, and 3) the low achievers are able to write correct words such as five hundreds and fifty three, fifty five, fifty six, three hundreds and fourty four, seven hundreds and seventy two, two hundreds and seventy five, and two hundreds fifty five. However, they still make mistake in writing one hundrade and fourteen, six hundrade and fivety three, fivety six, three hundrade and thirty three, seven hundrade and seventy two, two hundrade and fivety seven, four hundrade fivety five, one hundrade and eighty four, and four hundrate.

Based on the results of the analysis, the students who belong to the High Achievers can provide correct answers because they can understand the given instructions in the test, which are in English. As mentioned by Swain dan Lapkin (1982) in their research, classroom instruction in a second language will not harm the cognitive development of the students, including their intellectuality and intelligence. In addition, in order to prove their good ability in English, these students have also shown their productive skill, that is to write English words and phrases in the correct spelling. Hence, it is evident that the high achievers are more competent than the others in internalizing language, which supports Wagner-Gough and Hatch (1975) theories that the second language acquisition occurs due to some factors in which one of them is the input difference. Children tend to repeat, write, or speak the language input they learned when facing limited knowledge toward the question used vocabulary that they have not learned.

On the other hand, for Non High Achievers, the challenge to do Mathematics test in English is still considerably difficult. They can only understand some or a few of the given instructions, which are in English, which then influence their ability to provide correct answers. This is in line with Marsh et al (2000) who finds the tendency that in Hong Kong, the use of English as the classroom instruction of non-language classes, including Mathematics, has negative impact on the students' competence and skill of those non-language classes. In other words, when the complex concepts of Mathematics are taught in English, students with mid and low English competence will have problems to understand them because they do not only need to understand the Mathematics concepts but also the language of the classroom instruction. This is proven by the scores gained by the students which are only ranging from 16,35 to 75,77 , which is actually not very satisfying. One study related to this is a comparative study done by Madorah Smith (1930) to some monolingual pre-school children in lowa and some bilingual children in Hawaii. The findings show that the Hawaiian bilingual children produced more structural errors compared to the monolingual children in lowa. These findings support Meisel (2006) who finds a tendency of negative impact of bilingualism toward the cognitive, psychology, and linguistics development of a child.

However, in the process of learning the content-based language particularly in producing the language, it reveals that the learners in all levels undergo what Krashen (1981) called 'interlanguage' in that they have their own linguistic patterns to express their ideas which do not follow the English grammatical rules, spelling, or choice of words. Moreover, the learners have learned English through the teaching and learning process of Mathematics which is beneficial according to Dale, L. and Tanner, R. (2012) that language can be learned through content. Also, language comprehension comes prior to language production as what is stated by Krashen (1981) that learners should be exposed a lot to language input before they are able to use the language.

\section{CONCLUSIONS AND SUGGESTIONS}

In conclusion, the teaching and learning processes of Mathematics in the Laboratory Primary School of Universitas Negeri Malang, Indonesia are conducted in English as the instructional language. The English-based Mathematics instruction provides positive impact on the learners' language comprehension and language production for all the three achievers (high-med-low), except that the high achievers are more competent than the other two.

However, it is also interesting to underline that the teaching of Mathematics in English also has some negative impact toward the understanding of Mathematics concepts being taught because Mathematics itself is actually a quite difficult subject which require a thorough understanding of the concepts in order to be able to apply the formulas.

Therefore, the final conclusion of this paper is that the teaching of Mathematics in English does bring positive impact toward the second language acquisition of the children, however, it is also possible to bring negative impact toward the cognitive development of the non-English subjects being taught.

\section{REFERENCES}

Butler, Y.G \& Hakuta, K. 2006. Bilingualism and Second Language Acquisition. in T.K. Bathia \& W.C. Ritchie (Eds.), The Handbook of Bilingualism. (page. 114-144). UK: Blackwell Publishing Ltd. 
Aulia Apriana, Sri Rachmajanti \& Evynurul Laily Zen

Crystal, D. 2003. The Cambridge Encyclopedia of Language: Second Edition. Cambridge: Cambridge University Press.

Dale, L and Tanner, R. 2012. CLIL Activities; A Resource for Subject and Language Teachers. Cambridge: Cambridge University Press.

Darmojuwono, S \& Kushartanti. 2005. Aspek Kognitif Bahasa. Dalam Kushartanti dkk (Ed.), Pesona Bahasa. Langkah Awal Memahami Linguistik. (page. 15-31). Jakarta: Gramedia Pustaka Utama.

Fraenkel, J. R. \& Wallen, N. E. 1993. How to Design and Evaluate Research in

Education. New York: Mc Graw Hill.

Institute for Developing Laboratory of Education. 2010. Institute for Developing Laboratory of Education Newsletter (Warta BPLP). No.1, July 2010. Malang, Indonesia: Universitas Negeri Malang (UM).

Krashen, S.D. 1981. Second Language Acquisition and Second Language Learning. Oxford: Pergamon.

Meisel, J.G. 2006. The Bilingual Child. in T.K. Bathia \& W.C. Ritchie (Eds.), The Handbook of Bilingualism. (page. 114-144). UK: Blackwell Publishing Ltd.

O'Grady, W., et al. 2005. Contemporary Linguistics: An Introduction. Boston: Bedford/St. Martin's.

Parker, F \& Riley, K. 2005. Linguistics for Non-Linguists: A Primer with Exercises. Boston: Pearson International Edition.

Wagner-Gough, J. and Hatch, E. 1975. The importance of input data in second language acquisition studies. Language Learning 297-308 (pdf).

Saville-Troike, M. 2006. Introducing Second Language Acquisition. Cambridge: Cambridge University Press.

Steinberg, DD., Nagata, H., Aline DP. 2001. Psycholinguistics: Language, Mind, and World. Second Edition. England: Pearson Education Limited. 